\title{
Field Performance and Molecular Evaluations of Pecan Trees Regenerated from Somatic Embryogenic Cultures
}

\author{
Wagner A. Vendrame, Gary D. Kochert, ${ }^{1}$ Darrell Sparks, and Hazel Y. Wetzstein ${ }^{2}$ \\ Department of Horticulture, 1111 Plant Sciences Bldg., University of Georgia, Athens, GA 30602-7273
}

\begin{abstract}
AdDITIONAL INDEX wORDs. somaclonal variation, clonal fidelity, AFLP, Carya illinoinensis
AbSTRACt. Field evaluations were conducted of pecan [Carya illinoinensis (Wangenh.) C. Koch] trees regenerated via somatic embryogenesis to assess if the trees maintained clonal fidelity and exhibited true-to-type characteristics. Phenotypic and molecular comparisons were made of trees from two different tissue culture lines after 4 years in the field. Factors evaluated included shoot growth, leaf morphology, and susceptibility to fungal scab [Cladosporium caryigenum (Ellis \& Langl.) Gottwald] and southern pecan leaf phylloxera (Phylloxera russellae Stoetzel). Genetic fidelity was examined using amplified fragment length polymorphism (AFLP) analysis. Statistically significant differences were observed between the culture lines in phenotypic leaf characteristics (i.e., specific leaf weight and leaf length-to-width ratio), number of shoots per 1-year-old branch, and in the frequency of scab lesions on leaves. No between-line differences were observed in trunk caliper, average and total shoot growth, shoot length per cross-sectional area, or presence of phylloxera galls. AFLP analysis readily detected differences between culture lines. Cluster analysis generally grouped trees together that were regenerated from the same line. Trees within a culture line usually exhibited similar leaf characteristics, but not shoot growth or tree height. A few trees exhibited more extreme leaf characteristics and differed from each other. However, they were statistically similar to most of the other trees in the population evaluated. AFLP data revealed that some trees exhibited greater divergence and less similarity than other trees from the same line. The nature and significance of such variation at this time are not related to any detectable phenotypic differences.
\end{abstract}

Pecan (Carya illinoinensis) is an economically important nut crop that could benefit from development of an efficient, mass clonal propagation system. Conventional propagation of selected clones is usually by budding or grafting. Low propagation rates and poor survival and establishment have been problems in efforts to develop alternative conventional propagation methods (Wetzstein et al., 1996). Additionally, there are currently no means for commercial production of clonal rootstocks. The development and use of clonal rootstocks could introduce desirable characteristics available to other tree crops, such as reduction in variability of orchards, selective ion absorption, salinity tolerance, dwarfing, and nematode resistance (Hanna, 1987).

Somatic embryogenesis is a plant tissue culture technique with potential applications for mass clonal propagation, genetic transformation, and for use in studies of embryo development. In pecan, somatic embryogenesis was reported initially by Merkle et al. (1987). Improvement in somatic embryogenesis frequency (Wetzstein et al., 1989, 1990) and embryo maturation and germination (Burns and Wetzstein, 1995; Mathews and Wetzstein, 1993) have been achieved, so that consistent plant regeneration is possible. However, before somatic embryogenesis can be exploited for clonal propagation, genetic fidelity of regenerated plants must be evaluated and their field performance assessed.

Variation in plants regenerated from tissue culture has been observed in some systems. This tissue culture-induced somaclonal variation is a major concern in the production of true-to-type regenerants. For example, variation occurred in poplar (Populus L. sp.) trees regenerated from callus cultures (Antonetti and Pinon, 1993). Reuveni and Israeli (1990) found mutations in banana (Musa L. sp.) such as dwarfism, leaves with mosaic-like symptoms, and reddish leaf petioles. Plantain (Musa 'AAB') variants showing

Received for publication 13 June 1999. Accepted for publication 26 Apr. 2000. The cost of publishing this paper was defrayed in part by the payment of page charges. Under postal regulations, this paper therefore must be hereby marked advertisement solely to indicate this fact.

${ }^{1}$ Department of Botany.

${ }^{2}$ Corresponding author; e-mail: hywetz@arches.uga.edu. morphological and yield variations were identified by Vuylsteke et al. (1988). Strawberry (Fragaria $\times$ ananassa Duch.) plantlets showed dwarfism when regenerated under high concentrations of benzylaminopurine (BAP) and deformed and chlorotic leaves in plants derived from older cultures (Nehra et al., 1992). In contrast, Hammerschlag (1992) cited examples of phenotypic stability in regenerated plants of peach [Prunus persica (L.) Batsch (Peach Group)] and thornless loganberry (Rubus L. sp.), little or no variation in apple (Malus Mill. sp.), barley (Hordeum vulgare L.), cherry (Prunus avium $\times$ pseudocerasus L.), daylily (Hemerocallis L. sp.), or pear (Pyrus communis L.), and suggested that genotype and the nature of the explant are important determining factors for the occurrence of somaclonal variation.

Use of molecular methods has been proposed as a means of detecting culture-induced genetic variation. For example, random amplified polymorphic DNA (RAPD) has been used for detection of somaclonal variants in wheat (Triticum aestivum L.) (Brown et al., 1993) and peach (Hashmi et al., 1997). More recently, applicability of amplified fragment length polymorphism (AFLP) analysis has been evaluated for assessment of genetic variability in pecan somatic embryos (Vendrame et al., 1999).

This study evaluates pecan trees regenerated from somatic embryogenic cultures after growth in the field for about 4 years. Performance was evaluated by assessing morphological and growth characteristics including tree height, shoot growth, budbreak patterns, specific leaf weight, leaf length-to-width ratio, and susceptibility to scab (Cladosporium caryigenum) and southern pecan leaf phylloxera (Phylloxera russellae). In addition, genetic evaluations were made at the DNA level. The potential use of AFLP for evaluation of the genetic stability of regenerated trees was also assessed.

\section{Materials and Methods}

Plant material. Embryogenic pecan cultures were initiated and maintained as previously described (Mathews and Wetzstein, 1993; Wetzstein et al., 1996). Briefly, cultures were initiated from 
immature zygotic embryos. Cotyledonary explants were placed for 1 week on an induction medium composed of woody plant medium [WPM (Lloyd and McCown, 1980)] with $32 \mu \mathrm{M}$ naphthaleneacetic acid (NAA), $0.4 \mu \mathrm{M}$ BAP, casein hydrolysate at $1.0 \mathrm{~g} \cdot \mathrm{L}^{-1}$, inositol at $0.1 \mathrm{~g} \cdot \mathrm{L}^{-1}, 3 \%$ sucrose, and $0.6 \%$ GEL-GRO (ICN Biochemical, Irvine, Calif.). Thereafter, cultures were transferred and maintained on basal WPM medium, in the dark at $30^{\circ} \mathrm{C}$, with subculture at 3week intervals. Under these conditions cultures remained repetitively embryogenic.

To generate plants, individual somatic embryos were isolated, transferred to WPM for enlargement, then subjected to cold and desiccation treatments as described by Wetzstein et al. (1996). Embryos were germinated on semisolid WPM supplemented with silver nitrate at $5 \mathrm{mg} \cdot \mathrm{L}^{-1}$ and $1.44 \mu \mathrm{M}$ gibberellic acid (GA) at $27^{\circ} \mathrm{C}$, under a 16 -h photoperiod of $125 \mu \mathrm{mol} \cdot \mathrm{m}^{-2} \cdot \mathrm{s}^{-1}$ provided by coolwhite fluorescent lights, measured at culture height with a light meter (LI-COR, Lincoln, Nebr.). Germinated embryos were transferred to a sterile medium of 3 perlite : 1 vermiculite (v/v) and maintained in Magenta boxes (Magenta Corporation, Chicago, Ill.) covered with polyethylene sheets (Saran Wrap, Dow Chemical, Indianapolis, Ind.) when new shoot growth occurred. Plants were acclimatized gradually (Mathews and Wetzstein, 1993), field planted at the Horticulture Farm, near Watkinsville, Ga., in July to September 1994, then placed under 50\% shade cloth with micro sprinkler irrigation. Shade cloth was removed after the first growing season. Standard fertilization and spray schedules were used throughout the field growth period (French et al., 1983).

The trees used in this research were regenerated from two different culture lines designated A and B. Herein, a culture line was any somatic embryogenic tissue derived from the same immature zygotic embryo explant. Lines A and B originated from explants collected from 'Mahan' and 'Elliott' trees, respectively. Evaluations were made of seven trees from Line A and 15 trees from line $\mathrm{B}$ for phenotypic analysis. For molecular analysis, 10 trees from line $A$ and 18 trees from line B were used.

Phenotypic evaluations. Total shoot growth for each tree was measured at the end of the 1997 growing season. Total branch length including the main trunk was summed. Trunk caliper (diameter) was measured during Spring 1998 at $7.5 \mathrm{~cm}$ above soil level and trunk cross-sectional area calculated. As a means of evaluating budbreak patterns and relative shoot apical dominance, the number of shoots per 1-year-old branch that expanded to over $2 \mathrm{~cm}$ long was recorded during Spring 1998. Tree height was measured at the end of Summer 1998.

Leaf length-to-width ratio was calculated for leaves collected randomly from each tree during Summer 1998. Three replications of three leaves each were used for calculations. For each leaf, a leaflet from the midportion of the leaf was selected for area and dry weight (DW) measurements. Leaflet area was measured using a portable leaf area meter (LI-3000; LI-COR). Leaf weights were measured after leaves were oven-dried at $70^{\circ} \mathrm{C}$ to constant weight. Specific leaf weight was calculated based on DW per area. The measurements were made during Spring 1998.

Trees were evaluated for susceptibility to scab by rating leaflets for the presence of scab lesions which are characterized by circular necrotic areas. Evaluations were made during Spring 1998. The ratings used were 1) no scab lesions visible; 2) mild, lesions on $1 \%$ to $25 \%$ of leaflets; 3 ) moderate, lesions on $26 \%$ to $50 \%$ of leaflets; 4) severe, lesions on $51 \%$ to $75 \%$ of leaflets; and 5) very severe, leaves distorted with large coalesced lesions on $>75 \%$ of leaflets.

Susceptibility to the southern pecan leaf phylloxera was evaluated by assessing the extent of insect gall formation on leaflets.
Evaluations were made during Spring 1998. The ratings were 1) no galls visible; 2 ) galls on $1 \%$ to $25 \%$ of leaflets; 3 ) galls on $26 \%$ to $50 \%$ of leaflets; 4 ) galls on $51 \%$ to $75 \%$ of leaflets; and 5) galls on $>75 \%$ of leaflets.

Elemental analysis. Leaf elemental analysis was performed from leaflets collected randomly from the middle region of leaves that were located at the middle portion of shoots. Sampling was made during Summer 1997. Leaflets were oven-dried at $70^{\circ} \mathrm{C}$ to constant weight, ground, and redried just before assay. Analysis for $\mathrm{N}$ was performed using a autoanalyzer (Technicon Instruments Corp., Tarrytown, N.Y.). For all other elements (Al, As, B, Ba, Ca, $\mathrm{Cd}, \mathrm{Co}, \mathrm{Cr}, \mathrm{Cu}, \mathrm{Fe}, \mathrm{K}, \mathrm{Mg}, \mathrm{Mn}, \mathrm{Ni}, \mathrm{P}, \mathrm{Pb}, \mathrm{Si}, \mathrm{Sr}$, and $\mathrm{Zn}$ ) ground tissue was ashed overnight in a muffle furnace $\left(500{ }^{\circ} \mathrm{C}\right)$ and dissolved in $1 \mathrm{~mol} \cdot \mathrm{L}^{-1} \mathrm{HNO}_{3}$. Concentrations of elements were measured using an ICP spectrometer (model 9000; Thermo Jarrell Ash Corp., Franklin, Mass.) (Jones, 1977).

DNA ISOLATION AND QUANTIFICATION. Leaves were collected from individual trees and stored overnight in plastic bags at $4{ }^{\circ} \mathrm{C}$. For each sample, two to three leaflets were ground with liquid nitrogen. DNA was isolated using a modified cetyl trimethyl-ammonium bromide (CTAB) method as described in Vendrame et al. (1999).

AfLP Protocol. AFLP procedures followed the AFLP plant mapping protocol (Perkin Elmer Corp., 1997) as described in Vendrame et al. (1999). Restriction digestion of DNA was performed using two restriction enzymes: EcoRI and MseI. Three primer pairs were used: E-AAC/M-CTG, E-AAG/M-CTA, and EACA/M-CTC. The amplified PCR products were run on a $4.25 \%$ polyacrylamide gel, on an ABI Prism 377 DNA Sequencer (PE Applied Biosystems, Foster City, Calif.). Each AFLP procedure was performed twice to check for reproducibility.

Data ANALYSIS. Phenotypic and elemental data were subjected to analysis of variance procedures, general linear models procedures, and means separated by Tukey's studentized range test (SAS Institute Inc., 1989). Results for the AFLP data were analyzed using the ABI Prism Genescan 2.1 and the ABI Prism Genotyper 2.0 analysis softwares. A matrix of similarities was generated and analyzed by the NTSYS-pc software (Rohlf, 1992), using the DICE coefficient for two-state data. Clustering analysis was performed by using unweighted pair-group method, arithmetic average analysis (UPGMA) and a phenogram was generated.

\section{Results and Discussion}

\section{Phenotypic analysis}

BetweEn-Line Differences. Trees from the two culture lines exhibited vigorous growth. Tree height, total shoot growth, trunk caliper, and shoot length per trunk cross-sectional area were not significantly different (Table 1). Because trees regenerated from the two culture lines appeared to differ in branching habits, number of shoots were evaluated during Spring 1998 to assess these differences. Number of shoots per 1-year-old branch was 1.7 times greater in trees from line A versus line B (Table 1).

Apical dominance can have a pronounced effect on growth and form of individual branches and contributes significantly to the overall appearance of the tree crown (Zimmerman and Brown, 1980). Also affected are fruit production and harvesting (Kramer and Kozlowski, 1979). Aspects of tree form such as branch angle, amount of branching, shoot growth, and the degree of apical dominance are under genetic control (Kramer and Kozlowski 1979). Pecan cultivars may have characteristic branching habits that differ in the number of lateral branches along central branches. 'Mahan' has been characterized as having a multiple branching 
Table 1. Mean values for growth characteristics in pecan trees derived from two somatic embryogenic culture lines. ${ }^{\mathrm{z}}$

\begin{tabular}{|c|c|c|c|c|c|}
\hline $\begin{array}{l}\text { Culture } \\
\text { line }\end{array}$ & $\begin{array}{c}\text { Tree ht } \\
(\mathrm{cm})\end{array}$ & $\begin{array}{c}\text { Total } \\
\text { shoot } \\
\text { growth } \\
(\mathrm{cm})\end{array}$ & $\begin{array}{c}\text { Trunk } \\
\text { caliper } \\
(\mathrm{cm})\end{array}$ & $\begin{array}{c}\text { Shoot length/ } \\
\text { TCSA }^{\mathrm{y}} \\
\left(\mathrm{cm} \cdot \mathrm{cm}^{-2}\right)\end{array}$ & $\begin{array}{l}\text { Shoots/ } \\
\text { 1-year-old } \\
\text { branch } \\
\text { (no.) }\end{array}$ \\
\hline$\overline{A^{x}}$ & 203 & 261 & 2.7 & 53.1 & 6.4 \\
\hline $\mathrm{B}^{\mathrm{w}}$ & 211 & 203 & 2.4 & 62.5 & 3.7 \\
\hline Significance $^{v}$ & NS & NS & NS & NS & $*$ \\
\hline
\end{tabular}

Trunk and shoot values were measured at the end of the 1997 growing season. Data for expanding buds (no. shoots per 1-year-old branch) were collected Spring 1998.

${ }^{\mathrm{y}} \mathrm{TCSA}=$ trunk cross-sectional area.

${ }^{\mathrm{x}}$ Mean of 7 trees.

wMean of 15 trees.

'Means separation by Tukey's studentized range test.

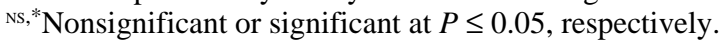

Table 2. Mean values for leaf morphological characteristics and ratings for the presence of scab (Cladosporium caryigenum) lesions and southern pecan leaf phylloxera (Russellae stuetzel) galls in pecan trees derived from two somatic embryogenic culture lines.

\begin{tabular}{|c|c|c|c|c|}
\hline $\begin{array}{l}\text { Culture } \\
\text { line }\end{array}$ & $\begin{array}{c}\text { Specific } \\
\text { wt } \\
\left(\mathrm{mg} \cdot \mathrm{cm}^{-2}\right)\end{array}$ & $\begin{array}{c}\text { Length-to-width } \\
\text { ratio } \\
\left(\mathrm{cm} \cdot \mathrm{cm}^{-1}\right)\end{array}$ & $\begin{array}{c}\text { Scab } \\
\text { rating }^{z}\end{array}$ & $\begin{array}{c}\text { Phylloxera } \\
\text { ratingy }^{y}\end{array}$ \\
\hline$\overline{\mathrm{A}^{\mathrm{x}}}$ & 7.7 & 1.7 & 1.5 & 2.3 \\
\hline $\mathrm{B}^{\mathrm{w}}$ & 9.6 & 1.5 & 3.7 & 1.5 \\
\hline Significance $^{v}$ & $*$ & $*$ & $* *$ & NS \\
\hline
\end{tabular}

${ }^{\mathrm{z}} 1=$ no scab lesions, $5=$ severe scab in $>75 \%$ of leaflets.

$\mathrm{y} 1=$ no insect galls, $5=$ galls in $>75 \%$ of leaflets.

xMean of 7 trees.

${ }^{w}$ Mean of 15 trees.

'Means separation by Tukey's studentized range test.

Ns,*,** Nonsignificant or significant at $P \leq 0.10$ or 0.05 or respectively.

habit (Sparks, 1992). The extensive number of shoots per 1-year-old branch observed in line A corresponds to characteristics for 'Mahan', the maternal parent.

Trees generally exhibited foliage that appeared healthy and free of nutrient deficiencies. Levels of elements were within normal concentrations for pecan leaves (Sparks, 1978). Elemental concentration between the two lines did not differ significantly (data not presented). In contrast, morphological leaf differences occurred between trees from the two lines. Trees from line A showed significantly lower specific leaf weights and significantly higher leaf length-to-width ratios compared to trees from line B (Table 2). Most leaves were pinnate and compound, characteristic of mature pecan leaves. However within a single tree, leaf morphology exhibited successive changes in maturation. Leaves in the basal portion of trees had simple, juvenile characteristics. Such changes in growth phase are observed commonly in seedling pecan trees and would likewise be anticipated in trees derived from somatic embryogenic cultures.

Significant differences in susceptibility to scab were observed among trees from the two culture lines (Table 2). Trees from line A exhibited little or no scab lesions on leaves. In contrast, leaves from line B had frequent lesions that severely distorted leaf morphology. The extremely low occurrence of scab lesions in line A is of interest. Longer term evaluations will be needed to verify the extent of scab resistance in this line. Significant differences in phylloxera galls were not observed between tree lines.

WitHIN-LINE DIFFERENCES. No marked differences, visible abnormalities or conspicuous branching patterns were observed in trees within the two lines. Trees regenerated within a culture line exhibited some variation in tree height, i.e., about 1.6-fold in line A and 1.7-fold in line B (Tables 3 and 4). Total shoot growth varied from 136 to $503 \mathrm{~cm}$ in line A and 145 to $541 \mathrm{~cm}$ in line B. Ritchie and Long (1986) evaluated the field growth of tissue-cultured Douglas fir [Pseudotsugamenziesii (Mirb.)Franco] trees that varied in tree size and plagiotropic growth in early evaluations. However, trees that exhibited large differences in size when young, became more similar in height 5 years after establishment. This suggests that early tree differences may not be due to inherent variation but rather to tree establishment. Additional field observations are needed in pecan to determine if tree size will become more uniform.

Leaves in trees within a line were consistent and characteristic for the species. No variegation or distortion was observed, unlike that seen in white spruce [Picea glauca (Moench) Voss] trees regenerated from somatic embryos (Isabel et al., 1996). Some white spruce trees were partially achlorophyllous and retained their divergent phenotypes even after 2 years in the greenhouse. In general, comparisons of pecan trees within each culture line resulted in little or no significant differences in leaf length-to-width ratio and specific leaf weight. An exception was one tree from line A, which showed a significant difference in specific leaf weight (Table 3). For leaf length-to-width ratio, trees were generally similar to each other, although tree 1 differed significantly from tree 7 . Likewise in trees from line $\mathrm{B}$, a range in values was obtained for both specific leaf weight and leaf length-to-width ratio (Table 4). Overall, trees were similar within the populations observed. Although a few trees exhibiting the more extreme upper and lower values were different from each other, they were statistically similar to most other trees.

In fruit crops, several studies have included morphological analyses and field evaluations of tissue culture-derived plants. Hammerschlag and Scorza (1991) observed no phenotypic anoma- 
Table 3. Comparison of morphological characteristics for pecan trees regenerated from culture line A.

\begin{tabular}{|c|c|c|c|c|}
\hline $\begin{array}{l}\text { Tree } \\
\text { no. }\end{array}$ & $\begin{array}{c}\text { Tree } \\
\text { ht } \\
(\mathrm{cm})\end{array}$ & $\begin{array}{c}\text { Total } \\
\text { shoot } \\
\text { growth } \\
(\mathrm{cm})\end{array}$ & $\begin{array}{c}\text { Specific } \\
\text { leaf } \\
\mathrm{wt} \\
\left(\mathrm{mg} \cdot \mathrm{cm}^{-2}\right)\end{array}$ & $\begin{array}{c}\text { Leaf } \\
\text { length-to-width } \\
\text { ratio } \\
\left(\mathrm{cm} \cdot \mathrm{cm}^{-1}\right)\end{array}$ \\
\hline 1 & 250 & 503 & $9.9 \mathrm{a}^{\mathrm{z}}$ & $2.0 \mathrm{a}$ \\
\hline 2 & 250 & 500 & $7.7 \mathrm{~b}$ & $1.8 \mathrm{ab}$ \\
\hline 3 & 226 & 483 & $7.6 \mathrm{~b}$ & $1.7 \mathrm{ab}$ \\
\hline 4 & 182 & 188 & $7.5 \mathrm{~b}$ & $1.7 \mathrm{ab}$ \\
\hline 5 & 176 & 183 & $7.4 \mathrm{~b}$ & $1.6 \mathrm{ab}$ \\
\hline 6 & 173 & 180 & $7.2 \mathrm{~b}$ & $1.6 \mathrm{ab}$ \\
\hline 7 & 161 & 136 & $6.8 \mathrm{~b}$ & $1.4 \mathrm{~b}$ \\
\hline
\end{tabular}

${ }^{\mathrm{z}}$ Mean separation within columns by Tukey's studentized range test, $P \leq 0.05$.

lies in own-rooted peach trees derived from axillary shoots. Likewise, Webster et al. (1985) observed no mutation in fruit characteristics of apple trees micropropagated from shoot tips. However, variation was observed among peach trees generated from callus that was derived from zygotic embryos (Hammerschlag, 1990; Hammerschlag et al., 1994). Zimmerman (1997) observed lack of clonal fidelity in micropropagated apple trees. Tissue culture resulted in the loss of the spur-type growth habit in some regenerants that resulted in significant and persistent differences in size, appearance, and flowering between spur and nonspur trees.

\section{Molecular analysis}

BETWEEN-LINE DIFFERENCES. With the three primer pairs used, a total of 361 amplified fragments were identified reliably with all of them being polymorphic. Other techniques such as RAPD and RFLP are more limited in terms of the number of markers obtained. In another study with pecan, 20 primer combinations produced 120 RAPD markers (H.Y. Wetzstein, unpublished data). Trees regenerated from lines A vs. B generally could be distinguished by frequent polymorphisms detected between the lines.

A phenogram (Fig. 1) was generated based on the similarity matrix coefficients for the trees evaluated in the two lines. Clustering analysis resulted in two distinct major groups. Group 1 was composed primarily of trees derived from line A, and Group 2 was comprised of trees primarily derived from line B. However, a few exceptions were observed. These unexpected groupings represent variants within a line and are discussed under within-line differences.

WiTHIN-LINE DIFFERENCES. In addition to the expected betweenline polymorphisms, some differences were detected within lines. All trees exhibited some polymorphisms regardless of whether they originated from the same or different lines. None of the trees exhibited $100 \%$ similarity, and the differences were repeatable in separate AFLP analyses. This suggests that AFLP analysis is very sensitive. However, trees regenerated from the same culture line generally showed higher similarity values than those originated from a different culture line.

Trees from line A generally grouped together as observed in the phenogram (Group 1, Fig. 1). A single tree derived from line A (tree 7) showed low similarity values compared with other trees derived from line A and exhibited closer relationship with trees in line B. Eleven of 18 trees derived from line B formed a major group in the phenogram (Group 2). Five trees from line B (trees 18, 19, 22, 24, and 26) grouped together with trees from line A. In addition, two trees were very divergent from all the other trees evaluated (trees 27 and 28). These two trees exhibited much lower similarity values than the trees in Groups 1 and 2.

As expected, trees regenerated from different culture lines exhibited phenotypic differences under field conditions in that the lines were initiated from explants differing in genotype. The two lines

Table 4. Comparison of morphological characteristics for pecan trees regenerated from culture line B.

\begin{tabular}{|c|c|c|c|c|}
\hline $\begin{array}{l}\text { Tree } \\
\text { no. }\end{array}$ & $\begin{array}{c}\text { Tree } \\
\text { ht } \\
(\mathrm{cm})\end{array}$ & $\begin{array}{c}\text { Total } \\
\text { shoot } \\
\text { growth } \\
(\mathrm{cm})\end{array}$ & $\begin{array}{c}\text { Specific } \\
\text { leaf } \\
\mathrm{wt} \\
\left(\mathrm{mg} \cdot \mathrm{cm}^{-2}\right)\end{array}$ & $\begin{array}{c}\text { Leaf } \\
\text { length-to-width } \\
\text { ratio } \\
\left(\mathrm{cm} \cdot \mathrm{cm}^{-1}\right)\end{array}$ \\
\hline 1 & 250 & 541 & $10.7 \mathrm{a}^{\mathrm{z}}$ & $1.8 \mathrm{a}$ \\
\hline 2 & 245 & 370 & $10.4 \mathrm{ab}$ & $1.7 \mathrm{ab}$ \\
\hline 3 & 235 & 366 & $10.3 \mathrm{abc}$ & $1.7 \mathrm{ab}$ \\
\hline 4 & 230 & 348 & $10.3 \mathrm{abc}$ & $1.7 \mathrm{ab}$ \\
\hline 5 & 230 & 338 & $10.1 \mathrm{abc}$ & $1.6 \mathrm{ab}$ \\
\hline 6 & 229 & 333 & $10.0 \mathrm{abc}$ & $1.6 \mathrm{ab}$ \\
\hline 7 & 228 & 310 & $9.9 \mathrm{abc}$ & $1.5 \mathrm{ab}$ \\
\hline 8 & 221 & 302 & $9.8 \mathrm{abc}$ & $1.5 \mathrm{ab}$ \\
\hline 9 & 212 & 292 & $9.6 \mathrm{abc}$ & $1.5 \mathrm{ab}$ \\
\hline 10 & 205 & 282 & $9.4 a b c$ & $1.5 \mathrm{ab}$ \\
\hline 11 & 205 & 217 & $9.2 \mathrm{abc}$ & $1.5 \mathrm{ab}$ \\
\hline 12 & 192 & 215 & $9.1 \mathrm{abc}$ & $1.5 \mathrm{ab}$ \\
\hline 13 & 189 & 207 & $9.0 \mathrm{abc}$ & $1.4 \mathrm{~b}$ \\
\hline 14 & 157 & 164 & $8.8 \mathrm{bc}$ & $1.4 \mathrm{~b}$ \\
\hline 15 & 140 & 145 & $8.8 \mathrm{bc}$ & $1.4 \mathrm{~b}$ \\
\hline
\end{tabular}

${ }^{\mathrm{z}}$ Mean separation within columns by Tukey's studentized range test, $P \leq 0.05$. 


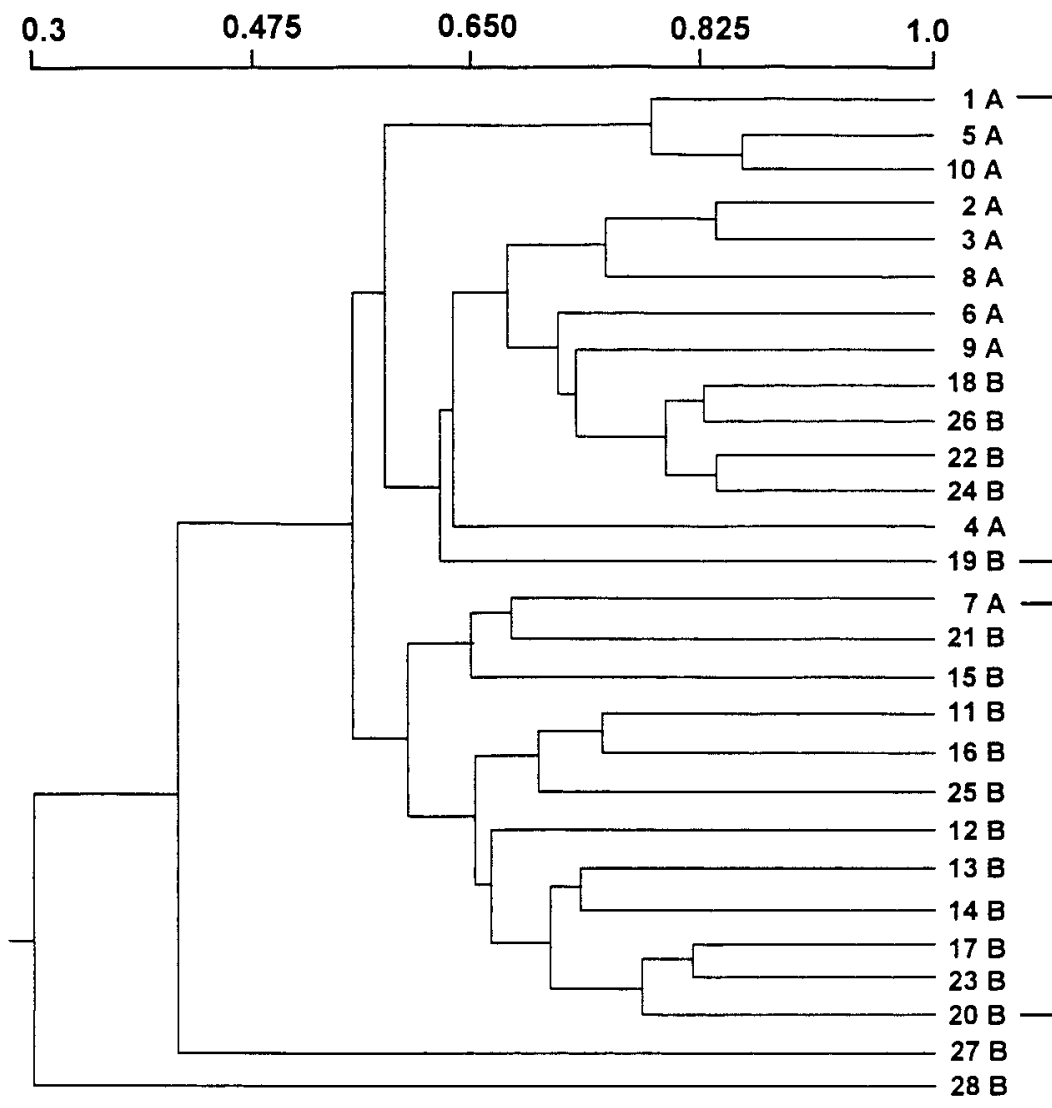

Fig. 1. Phenogram for pecan trees regenerated from two somatic embryo lines. Trees numbered 1 to 10 were regenerated from line A; trees numbered 11 to 28 were regenerated from line $\mathrm{B}$. Similarity indexes are shown at the top bar. $\mathrm{A}=$ a tree from line $\mathrm{A} ; \mathrm{B}=\mathrm{a}$ tree from line $\mathrm{B}$.

exhibited significant differences in leaf morphology, shoot growth patterns, and scab susceptibility. This was in accordance with genotypic evaluations using AFLP, which detected high degrees of polymorphism between the two lines. Trees regenerated from different lines tended to group separately.

No abnormalities were observed in trees derived from somatic embryogenic cultures after growth in the field for 4 years. Generally, leaf phenotypic characteristics differed between lines, but were similar within lines. Tree height and total shoot growth differed markedly from tree to tree. However, our observations are limited to those of young trees. Longer term evaluations are required to determine if this culture system produces uniform, true-to-type plants.

In contrast, AFLP analysis showed polymorphisms that currently were not reflected in phenotypic variations. Potentially, the detected genetic variations may affect phenotypic characteristics that are expressed at a later time. Some characteristics, such as flowering, fruit characteristics, and yield require long-term field evaluations. According to Sparks (1992), pecan cultivar evaluations cannot be complete until trees are mature with a minimum testing period of $>20$ years. Alternatively, it is possible that differences detected by AFLP do not affect gene expression or reflect horticulturally important characteristics. The usefulness of AFLP to evaluate somatic embryo-derived plants for clonal fidelity will be dependent on how closely polymorphic loci can be correlated with economically important phenotypic characteristics.

\section{Literature Cited}

Antonetti, P.L.E. and J. Pinon. 1993. Somaclonal variation within poplar. Plant Cell Tissue Organ Cult. 35:99-106. Brown, P.T.H., F.D. Lange, E. Krauz, and H. Lörz. 1993. Analysis of single protoplasts and regenerated plants by PCR and RAPD technology. Mol. Gen. Genet. 237:311317.

Burns, J.A. and H.Y. Wetzstein. 1995. Development and germination of pecan somatic embryos derived from liquid culture. In Vitro Cell. Dev. Biol. 31:72-78.

GROUP 1

French, C.M., H.C. Ellis, and P. Bertrand. 1983. Georgia pecan spray guide. Univ. Ga. Coop. Ext. Serv. Bul. 841.

Hammerschlag, F.A. 1990. Resistance responses of plants regenerated from peach callus cultures to Xanthomonas campestris pv. pruni. J. Amer. Soc. Hort. Sci. 115:1034 1037.

Hammerschlag, F.A. 1992. Somaclonal variation, p. 35-36. In: F.A. Hammerschlag and R.E. Litz (eds.). Biotechnology of perennial fruit crops. vol. 8. CAB Intl., Wallingford, U.K.

Hammerschlag, F.A. and R. Scorza. 1991. Field performance of micropropagated, own-rooted peach trees. J. Amer. Soc. Hort. Sci. 116:1089-1091.

Hammerschlag, F.A., D.J. Werner, and D.F. Ritchie. 1994. Stability of bacterial leaf-spot resistance in peach regenerants under in-vitro, greenhouse and field conditions. Euphytica 76:101-106.

GROUP 2

Hanna, J.D. 1987. Pecan rootstocks, p. 401-410. In: R.C Rom and R.F. Carlson (eds.). Rootstocks for fruit crops. Wiley, New York.

Hashmi, G., R. Huettel, R. Meyer, L. Krusberg, and F. Hammerschlag. 1997. RAPD analysis of somaclonal variants derived from embryo callus cultures of peach. Plant Cell Rpt. 16:624-627.

Isabel, N., R. Boivin, C. Levasseur, P-M. Charest, J. Bousquet, and F.M. Tremblay. 1996. Occurrence of somaclonal variation among somatic embryo-derived white spruces (Picea glauca, Pinaceae). Amer. J. Bot. 83:1121-1130.

Jones, J.B., Jr. 1977. Elemental analysis of soil extracts and plant tissue ash by plasma emission spectroscopy. Commun. Soil Sci. Plant Anal. 8:349-365 Kramer, P.J. and Kozlowski. 1979. Physiology of woody plants. Academic Press, New York. Lloyd, G. and B. McCown. 1980. Commercially feasible micropropagation of mountain laurel, Kalmia latifolia, by use of shoot-tip culture. Proc. Intl. Plant Prop. Soc. 30:421-427.

Mathews, H. and H.Y. Wetzstein. 1993. A revised protocol for efficient regeneration of somatic embryos and acclimatization of plantlets in pecan, Carya illinoensis. Plant Sci. 91:103-108.

Merkle, S.A., H.Y. Wetzstein, and H.E. Sommer. 1987. Somatic embryogenesis in tissue cultures of pecan. HortScience 22:128-130.

Nehra, N.S., K.K. Kartha, C. Stushnoff, and K.L. Giles. 1992. The influence of plant growth regulator concentrations and callus age on somaclonal variation in callus culture regenerants of strawberry. Plant Cell, Tissue Organ Cult. 29:257-268.

Perkin Elmer Corp. 1997. AFLP plant mapping protocol. P/N 4303146 Rev. A., Perkin Elmer Corp., Foster City, Calif.

Reuveni, O. and Y. Israeli. 1990. Measures to reduce somaclonal variation in in vitro propagated bananas. Acta Hort. 275:307-313.

Ritchie, G.A. and A.J. Long. 1986. Field performance of micropropagated Douglas Fir. N. Z. J. For. Sci. 16:343-356.

Rohlf, F.J. 1992. NTSYS-pc. Numerical taxonomy and multivariate analysis system. version 1.70. Exeter Software, Setauket, N.Y.

SAS Institute Inc. 1989. SAS/STAT user's guide, version 6.0. 4th ed. SAS Inst., Cary, N.C. Sparks, D. 1978. Nutrient concentration of pecan leaves associated with deficiency symptoms and normal growth. HortScience 13:256-257.

Sparks, D. 1992. Pecan cultivars: The orchard's foundation. Pecan Production Innovations, Watkinsville, Ga.

Vendrame, W., G. Kochert, and H.Y. Wetzstein. 1999. AFLP analysis of variation in pecan somatic embryos. Plant Cell Rpt. 18:853-857.

Vuylsteke, D., R. Swennen, G.F. Wilson, and E. De Langhe. 1988. Phenotypic variation among in-vitro propagated plantain (Musa sp. cultivar 'AAB'). Scientia Hort. 36:79-88.

Webster, A.D., V.H. Oehl, J.E. Jackson, and O.P. Jones. 1985. The orchard establishment, growth and precocity of four micropropagated apple scion cultivars. J. Hort. Sci. 60:169-180.

Wetzstein, H.Y., J.R. Ault, and S.A. Merkle. 1989. Further characterization of somatic embryogenesis and plantlet regeneration in pecan, Carya illinoinensis. Plant Sci. 64:193201.

Wetzstein, H.Y., J.R. Ault, and S.A. Merkle. 1990. Factors influencing somatic embryogenesis and plantlet regeneration in pecan, Carya illinoinensis. Acta Hort. 280:69-73.

Wetzstein, H.Y., A.P.M. Rodriguez, J.A. Burns., and H.N. Magner. 1996. Carya illinoensis (pecan), p. 50-75. In: Y.P.S. Bajaj (ed.). Biotechnology in agriculture and forestry. vol 35. Springer-Verlag, New York.

Zimmerman, R.H. 1997. Orchard variation in micropropagated trees of 'Redspur Delicious' apple. HortScience 32:935-936.

Zimmerman, M.H. and C.L. Brown. 1980. Trees structure and function. Springer-Verlag, New York. 